\title{
sciendo
}

CIVIL AND ENVIRONMENTAL ENGINEERING REPORTS

E-ISSN 2450-8594

CEER 2021; 31 (3): 0018-0036

DOI: $10.2478 /$ ceer-2021-0032

Original Research Article

\section{PHYSICOCHEMICAL CHARACTERIZATION OF THE QUALITY OF GROUNDWATER: CASE STUDY OF THE TEBESSA PLAIN (NORTH-EAST ALGERIA)}

\author{
Lassaad GHRIEB ${ }^{1}$, Ammar MAOUI $^{2}$, Essia BOUDJEBIEUR ${ }^{3}$, Yacine GUEROUI ${ }^{2}$ \\ ${ }^{1}$ Water Resource Laboratory \& Sustainable development REDD, University 8 May \\ 1945, Guelma, Algeria \\ ${ }^{2}$ Laboratory of Civil Engineering and Hydraulics, University 8 May 1945, Guelma, \\ Algeria \\ ${ }^{3}$ Water Resource Laboratory \& Sustainable development REDD, \\ University of Annaba
}

\begin{abstract}
In order to characterize the physicochemical quality of groundwater, and to examine the behavior of factors influencing water chemism in the Tebessa Plain, which is part of a semi-arid region located in the northeast of Algeria, physicochemical analyses were carried out on 32 water samples from the Mio-Plio quaternary water table. In the east of the study region, in the Djebissa area, most of the Triassic formations form a depression made up of masses of gypsiferous clay, where some outcrops of Triassic dolomites appear together with several blocks of carbonate rocks, torn off during the AptianAlbian age. In the center and to the west of the plain, carbonate formations are represented by a significant layer of limestone marl and marl from the Cretaceous to Tertiary periods.

The results obtained showed that the quality of the water is influenced by the heterogeneity of the geological formations. The concentrations of chlorides, sulphates, and sodium are high in the eastern part of the study area, which can be explained by the impact of gypsum formations, confirmed by the $\mathrm{Sr}^{2+} / \mathrm{Ca}^{2+}$ ratio being greater than $3 \%$ for the majority of samples. In the wells of the Tebessa and Ain Chabro areas, the
\end{abstract}

\footnotetext{
${ }^{1}$ Corresponding author: Water Resource Laboratory \& Sustainable development REDD, University 8 May 1945, Guelma, Algeria, e-mail: ghrieblassaad@yahoo.fr
} 
concentrations of calcium, magnesium, and bicarbonates increase due to the predominance of carbonate formations of borders. The use of the statistical tool confirmed the evaporitic origin of the anions, especially in the east of the study region.

Keywords: physicochemical quality, semi-arid region, Tebessa, gypsiferous formations, $\mathrm{Sr}^{2+} / \mathrm{Ca}^{2+}$ ratio

\section{INTRODUCTION}

Groundwater is seen as an alternative solution to deal with problems of water scarcity in arid and semi-arid regions and, therefore, this area of research has attracted many authors such as Rouabhia et al. [2009, 2010] and Fehdi et al. $[2015,2016]$, to study geology and water resources. Groundwater contains different types of minerals transported in solution, where the types and concentrations of these minerals are mainly conditioned by several factors such as rock chemistry, surface and groundwater interactions, geological setting (which offers a preferred path for groundwater flow) and any other source for water pollution.

Groundwater chemistry represents the end product of the interaction between water and rocks from different geological eras. This explains why groundwater contains varieties of many dissolved chemical constituents with different types and concentrations.

The chemical quality of groundwater can be influenced by the chemical composition of the soils and rocks through which the water flows, depending on the mineral dissolution, mineral solubility, ion exchange, oxidation, reduction etc., in addition to the sources of anthropogenic activities (population explosion, poor sanitary conditions, application of fertilizers and pesticides for higher crop yields - without understanding the chemical characteristics of soils $[1,8,10,16]$. The chemical composition of the resulting solutions is, therefore, informative of the nature of the aquifer.

The problem of mobile water resources not only arises in terms of the quantity available; the quality of the water is beginning to pose serious problems $[11,18]$. We are now faced with the need to use, manage, and protect water sustainably, and to ensure that it balances the needs and uses because it is the foundation of all life on Earth $[4,12,13]$. Aridity affects a large part of Algeria and, with the persistence of drought, surface water becomes scarce, groundwater is reduced, and the quality deteriorates with the increase of salinity $[5,19]$.

The surrounding rocks in the region have a direct impact on the concentration of different water quality parameters. Alkaline earth elements $\left(\mathrm{Ca}^{2+}\right.$ and $\left.\mathrm{Mg}^{2+}\right)$ and Alkaline elements $\left(\mathrm{Na}^{+}\right.$and $\left.\mathrm{K}^{+}\right)$are generally produced by the weathering and erosion of carbonate and silicate minerals such as calcite, dolomite, and gypsum, 
having a dissolution capacity under different environmental conditions $[14,15$, 27]. The dissolution of evaporites also has an impact on the physicochemical characteristics of groundwater $[8,17,26]$.

The aim of this work is to characterize the physicochemical parameters, and to determine the impact of geological formations on the chemical composition of groundwater in a semi-arid region in the far east of Algeria, affected by the lack of and degradation of the quality of its groundwater.

\section{GEOGRAPHICAL SITUATION}

Tebessa, a border town with Tunisia, is located in the far north-east of Algeria (Fig.1), at the edge of the desert, about $230 \mathrm{~km}$ south of Annaba on the Mediterranean coast. The region is limited to the South by the sector of Biskra, to the West by that of Constantine, and to the East by the Algerian-Tunisian border.

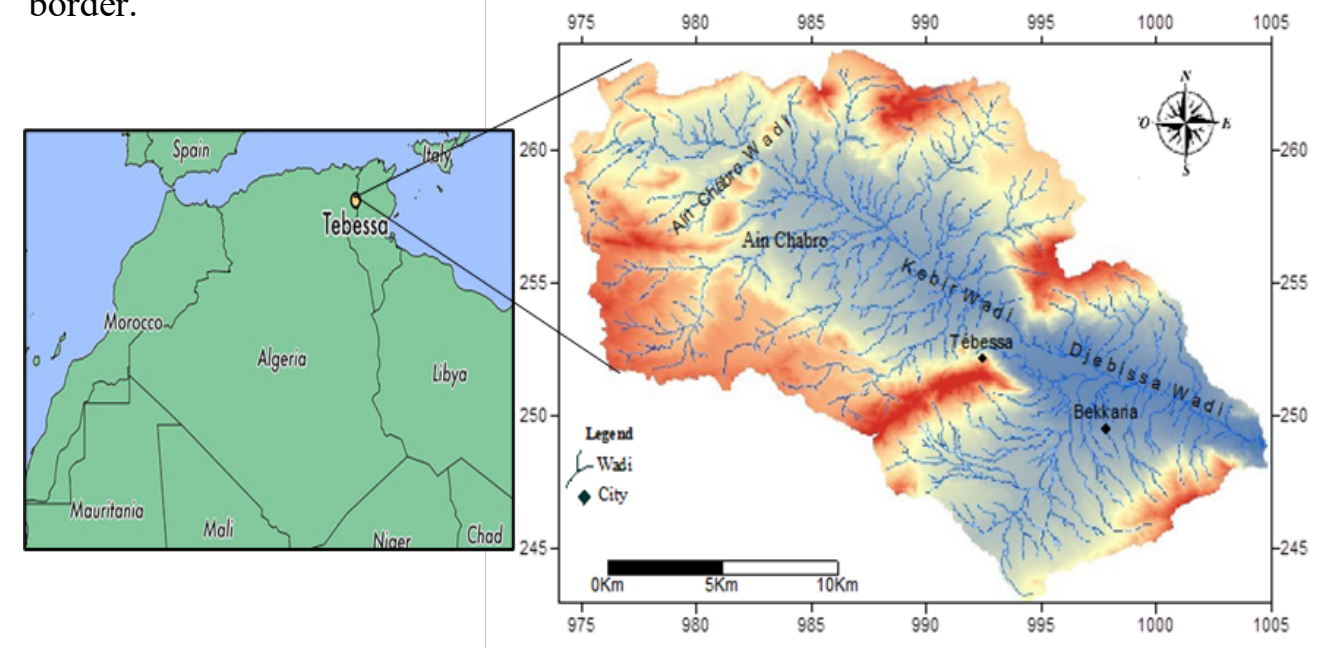

Fig.1. Geographical situation of the study area

\subsection{Geological and hydrogeological overview of the study area}

The study area is part of the Northeastern Auresian structure (Aures Nememcha) of the Atlas Saharian [9]. It consists mainly of the following formations:

- A Triassic diapiric formation dislocating underlying formations in Jebel Djebissa.

- Carbonated formations represented by important limestone-marl layers and Cretaceous to Tertiary marls (Fig.2). 
The climatological study of the Tebessa region shows that the climate is typically semi-arid continental type (cold winter and hot summer).

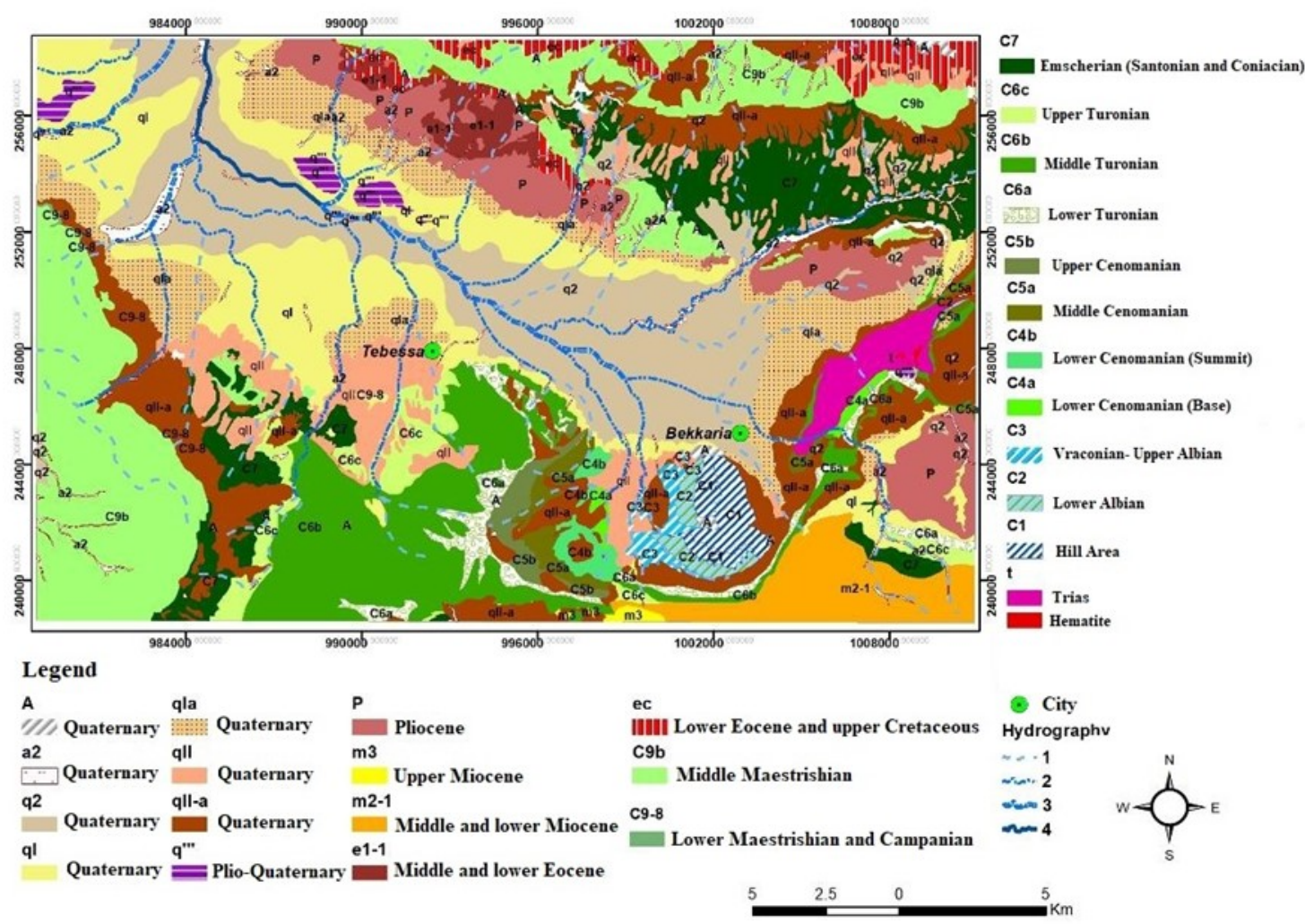

Fig.2. Geology of the study area

Observation of the piezometric map shows an irregular piezometric surface, where the morphology of the curves indicates a flow direction South-East NorthWest. It also identifies three distinct sectors (Fig. 3).

The piezometric map also shows that the waters coming from Djebel Djebissa reach the water table by Wadi Djebissa. The waters crossing this zone will feed the aquifer and influence the chemical composition of its waters by the Triassic formations of Djebel Djebissa. 


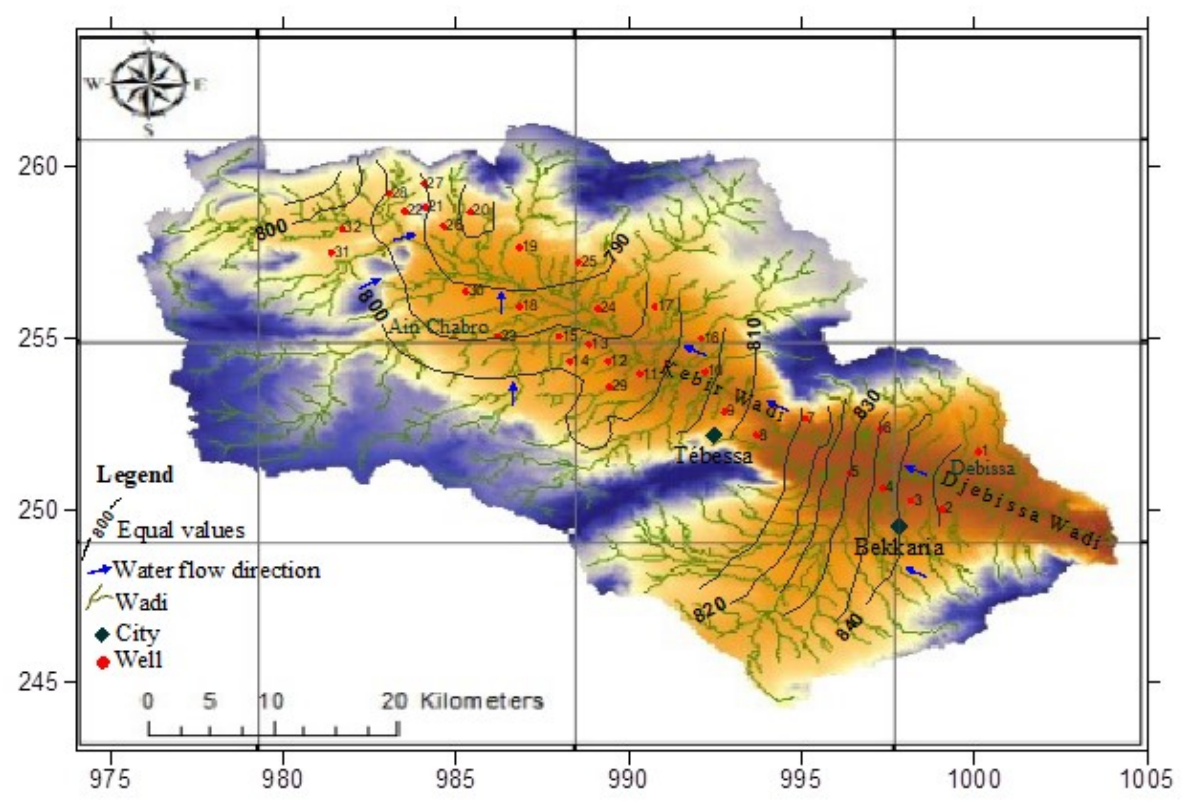

Fig.3. Piezometric map of Tebessa Plain (March 2009)

\section{MATERIALS AND METHODS}

The elemental chemical analyses were carried out at the Annaba Earth Sciences Laboratory, at the laboratory of the study, and at the research center applied to the development of Ferphos, HYDROSID, DRA, at the laboratory of the University of Lille, and the University of Franche-Comté in Besançon, France. The samples were filtered beforehand and stored at a temperature of $4^{\circ} \mathrm{C}$.

The methods used in this study are atomic absorption spectrometry (PerkinElmer) for analysis of $\mathrm{Ca}^{2+}, \mathrm{Mg}^{2+},\left(\mathrm{Na}^{+}+\mathrm{K}^{+}\right)$, and $\mathrm{Sr}^{2+}$; titrimetric determination for $\left(\mathrm{HCO}_{3}{ }^{-}\right)$; and colorimetric assays for $\left(\mathrm{Cl}, \mathrm{SO}_{4}{ }^{2-}\right)$. The physical parameters such as $\mathrm{pH}$ and Electrical conductivity undergo transformations once the water has been cut from their initial interaction medium and have been measured in situ [9]. The same conditions were respected for all measurements (same equipment and same measurement protocol).

The samples were taken during the period of high-water, on about thirty domestic wells (Figure 3) whose average depth is less than $50 \mathrm{~m}$. The study area was divided into three sub-zones: Djebissa, Tebessa, and Ain Chabro. 


\section{RESULTS AND DISCUSSION}

The interpretations will be in accordance with the direction of flow, that is to say from east to west; from Djebissa to Ain Chabro via Tebessa, which corresponds to the center of the plain. For this purpose, we have chosen six representative wells for each area.

\subsection{Electrical conductivity (EC)}

The electrical conductivity of water is its ability to let electrical charges move freely. This characteristic depends on the quantity of ions present in solution. Electrical conductivity, here expressed in $\mu{\mathrm{S} . \mathrm{cm}^{-1}}^{-1}$, is, therefore, an expression of the mineralization of water. High conductivity is a sign of significant mineralization (also called salinity). Mineralization is highly dependent on transit time and rocks being placed in contact with water but also on possible anthropogenic impacts [25].

The values of the measured electrical conductivity, allow the following observations (Fig. 4):

- in the Djebissa area, north of Bekkaria, the values are high, reaching 8500 $\mu \mathrm{S} . \mathrm{cm}^{-1}$, especially during the low water period due to contamination by the evaporites of Djebel Djebissa. A second intermediate zone lies in the Tebessa area, the center of the plain, where conductivity values oscillate between 400 and $1500 \mu \mathrm{S} . \mathrm{cm}^{-1}$. To the West, in the Ain Chabro area, we notice a decrease in the values of the conductivity between 300 and $800 \mu \mathrm{S} . \mathrm{cm}^{-1}$ ) [9].

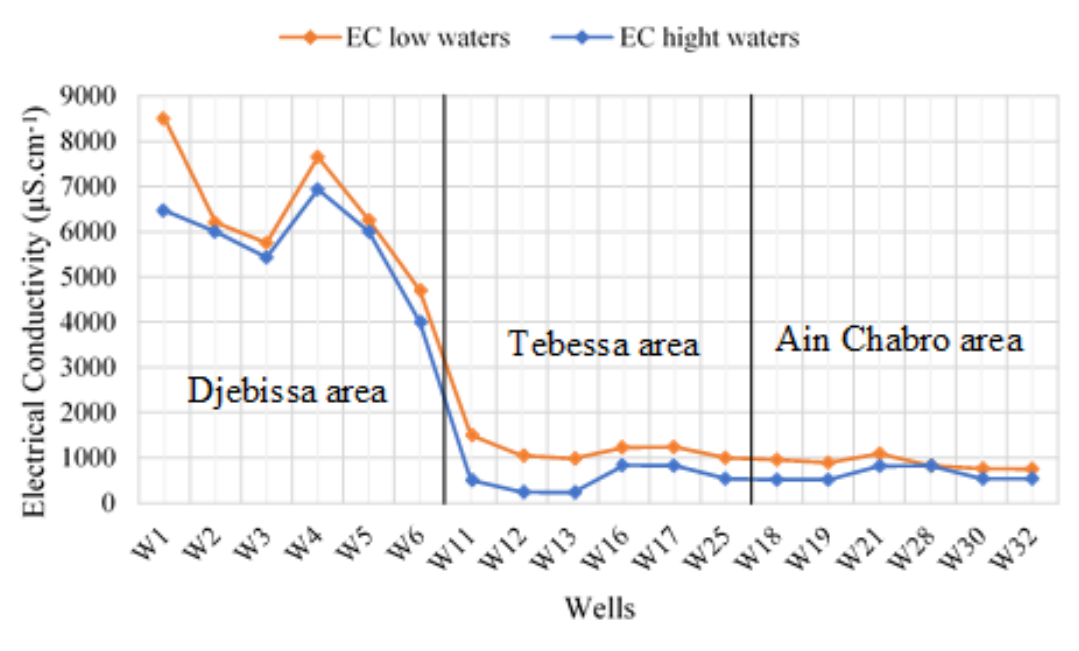

Fig.4. Evolution of electrical conductivity in well waters 


\subsection{Evolution of elements Calcium, Magnesium and Sodium}

The following graph (Fig. 5) illustrates the evolution of the three cations $\mathrm{Ca}^{2+}$, $\mathrm{Mg}^{2+}$, and $\mathrm{Na}^{+}$.

The calcium ion can come either from the dissolution of carbonate formations or from the dissolution of gypsum formations, or both at the same time. In the study area, the average calcium concentration reaches $250 \mathrm{mg} / \mathrm{l}$. The following graph (fig. 5) shows a heterogeneous variation in concentrations. Thus, only a few wells indicate high concentrations, as is the case for W1 $(350 \mathrm{mg} / \mathrm{l})$ and W6 $(280 \mathrm{mg} / \mathrm{l})$ in the Djebissa area, in the center of the plain (Tebessa) - W13 (250 $\mathrm{mg} / \mathrm{l})$, and in the Ain Chabro area - wells W18 (300 mg/l) and W32 (320 mg/l) show high levels of calcium. This situation is generated by the position of these wells relative to the outcrop of limestone formations.

In nature, magnesium often accompanies calcium. We notice a variation in the average concentration; it decreases from $140 \mathrm{mg} / 1$ to $70 \mathrm{mg} / \mathrm{l}$. The high magnesium concentrations are due to the dissolution of the dolomitic limestones of the borders. The highest levels are located in the Ain Chabro area, where water is supplied by the limestone borders in the region.

The sodium concentration varies between 50 and $370 \mathrm{mg} / \mathrm{l}$ (Fig. 5). The highest concentrations are located in the East zone (Djebissa area), and in the center of the plain (Tebessa area), where the concentrations are around $100 \mathrm{mg} / \mathrm{l}$. In the West of the plain (Ain Chabro area), the levels are around $130 \mathrm{mg} / \mathrm{l}$. The decrease observed between Djebissa and Tebessa is probably caused by the exchange of bases, in fact, the water arriving from the East, rich in sodium, in contact with the soil releases the sodium and recovers the calcium contained in the soil [24]. In the Djebissa area, the calcium rich outcrop evaporates, facilitating the exchange of bases between water and clay formations [9]. 


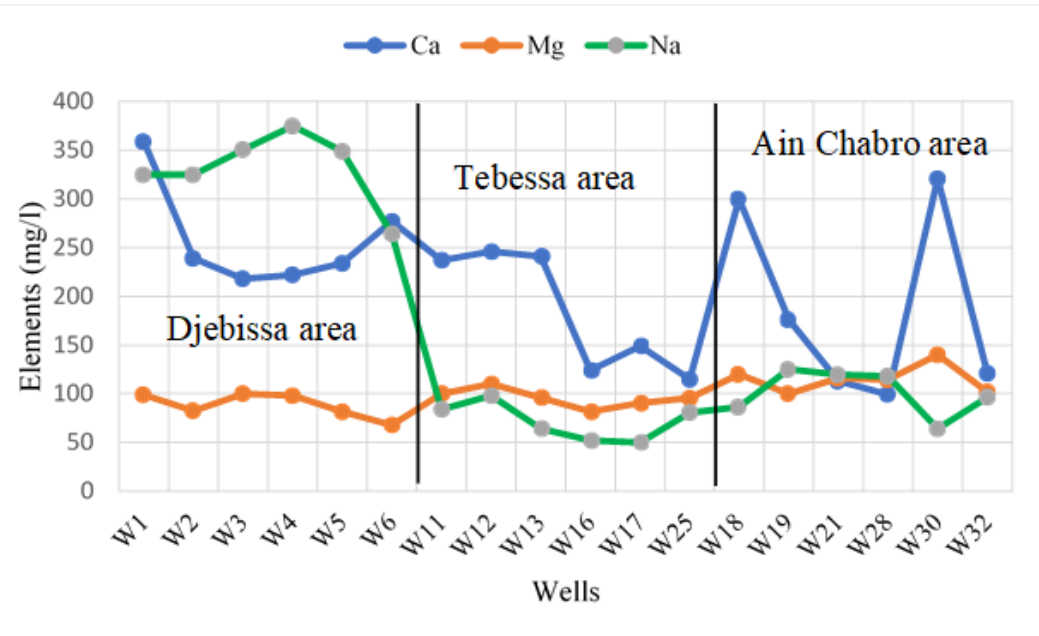

Fig.5. Evolution of calcium, magnesium, and sodium in well waters

\subsection{Evolution of elements - Chlorides, Sulphates, and Bicarbonates}

In the following graph (Fig.6), grouping the elements $\mathrm{Cl}^{-}, \mathrm{SO}_{4}{ }^{2-}$, and $\mathrm{HCO}_{3}{ }^{-}$, we notice that:

From Djebissa to Tebessa, there is a drop in concentrations of chloride from $1000 \mathrm{mg} / 1$ to $200 \mathrm{mg} / \mathrm{l}$. This evolution indicates that Djebel Djebissa is a potential source of chlorides. In the Ain Chabro area, the concentrations are identical to those observed in Tebessa. In this zone, the quality of the water is influenced by the limestone curbs (Fig. 6).

The presence of sulphates in the water is related to the dissolution of gypsum by leaching of evaporite deposits from Djebel Djebissa, north of Bekkaria, according to the relationship 4.1:

$$
\mathrm{CaSO}_{4}+2 \mathrm{H}_{2} \mathrm{O}=\mathrm{Ca}^{2+}+\mathrm{SO}_{4}{ }^{2-}+2 \mathrm{H}_{2} \mathrm{O}
$$

The highest values are recorded in the Djebissa area, with an average of 1000 $\mathrm{mg} / \mathrm{l}$, because of the dissolution of the Triassic formations, evidenced by the phenomenon of evaporation.

These concentrations decrease towards the center of the plain. In the Ain Chabro area, the concentrations are of the order of $200 \mathrm{mg} / \mathrm{l}$ but can reach lower levels (100 mg/l) (Fig.6).

The presence of bicarbonates in the water is due to the dissolution of the carbonate formations which border the water table, according to the following reaction 4.2:

$$
\mathrm{CaCO}_{3}+\mathrm{H}_{2} \mathrm{O}+\mathrm{CO}_{2}=2 \mathrm{HCO}_{3}{ }^{-}+\mathrm{Ca}^{2+}
$$

A high content of bicarbonates is recorded in the Ain Chabro area, being around $630 \mathrm{mg} / \mathrm{l}$. This means that the lateral borders, by dilution effect, enrich the 
waters with bicarbonates. In the Djebissa area, the concentrations are around 150 $\mathrm{mg} / \mathrm{l}$, this contribution comes from the limestone formations of Djebel Bouroumane. In Tebessa, in the center of the plain, the concentrations reach 450 $\mathrm{mg} / \mathrm{l}$, probably due to the supply of the water table through the southern borders [18].

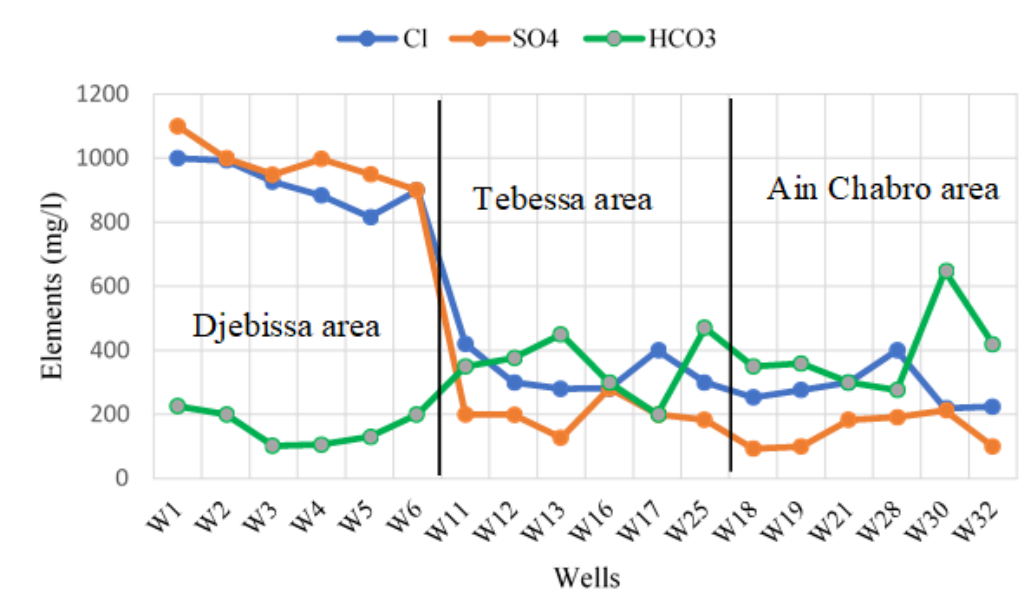

Fig.6. Evolution of calcium, magnesium, and sodium in well waters

\subsection{Evolution of the $\mathrm{Sr}^{2+/} \mathrm{Ca}^{2+}$ ratio}

The previous results confirmed that evaporitic formations influence the chemistry of the water. To support this hypothesis, a monitoring of the element strontium in the wells of the region, over a period of 8 months, was established. this variation indicates the evaporitic origin of the salinity.

Strontium $\left(\mathrm{Sr}^{2+}\right)$ is an element linked to evaporites. It is very weakly integrated into the carbonate network and is poorly adsorbed by clays. The high levels of $\mathrm{Sr}^{2+}$ in water can only be explained by the dissolution of Celestite $\left(\mathrm{SrSO}_{4}\right)$, a mineral associated with gypsum. It thus forms a good marker for the presence of evaporites [3]. Strontium, therefore, makes it possible to distinguish the sulphates resulting from the oxidation of sulphides (lower content) from those resulting from the dissolution of evaporites (higher content).

The ionic ratio of $\mathrm{Sr}^{2+} / \mathrm{Ca}^{2+}$ is characteristic of an evaporitic origin if it is equal to or greater than $3 \%$ [2].

In this part of the study, two wells were used (W1 and W8) to confirm the evaporitic origin of water in the region, the first of which is located a few meters from the Triassic formations and the second which is quite distant. 
Graphs of the $\mathrm{Sr}^{2+} / \mathrm{Ca}^{2+}$ ratios of wells 1 and 8 show very high values, greater than $3 \%$, indicating an influence from the evaporitic formations, which suggests that Djebel Djebissa (diapir) directly influences the salinity of the waters (Fig. 7). The results of the $\mathrm{Sr}^{2+} / \mathrm{Ca}^{2+}$ ratio show a direct influence by the evaporite formations on the mineralization, and concern the water collected by the first well (W1) located in the region of Djebissa, upstream of the aquifer system supplied by water passing through the evaporite formations [9]. Further from the first well, the water captured by well 8 also shows an influence by evaporites through the $\mathrm{Sr}^{2+} / \mathrm{Ca}^{2+}$ ratio, but to a lesser degree than the first [21].
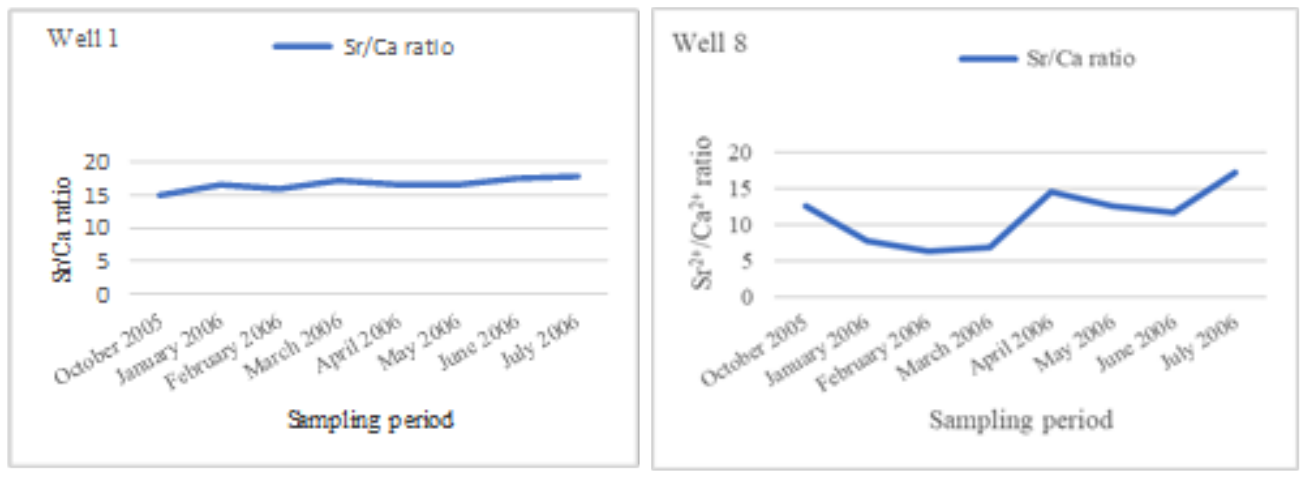

Fig.7. $\mathrm{Sr}^{2+} / \mathrm{Ca}^{2+}$ ratio changes at the extreme wells (W1, W8)

\subsection{Saturation indices}

The dissolution of a mineral in water can be described by a state of equilibrium: when the water is in contact with a mineral, the concentration of the solution increases to reach a maximum for the given physicochemical conditions. The solution is then said to be saturated with this mineral.

The state of saturation is expressed by the saturation index 4.3

$$
\mathrm{SI}=\log (\mathrm{K})-\log (\mathrm{PI})
$$

With $\mathrm{K}$ the equilibrium constant and PI the ionic product.

Three cases are possible:

$\mathrm{SI}<0$ signifies an undersaturation of a solution with respect to a mineral;

$\mathrm{SI}=0$ indicates a state of saturation;

$\mathrm{SI}>0$ demonstrates a supersaturation. 
In our study, mineral saturation indices (calcite, dolomite, gypsum, and anhydrite,) and chemical equilibria were calculated using the PhreeqC program [20].

The results indicate the presence of several minerals, in particular anhydrite, gypsum, calcite, and dolomite, whose saturation indices vary within a small interval. The analysis of the results allowed us to determine the minerals that can influence the chemical composition (Fig.8). Among the most important, we note:

\section{Calcite $\left(\mathrm{Ca}^{2+} \mathrm{CO}_{3}\right)$}

All the values are positive, this is due to a precipitation of the calcite, from which there is a possible enrichment of the waters in calcium bicarbonate.

Dolomite $\left(\mathrm{Ca}^{2+} \mathrm{Mg}\left(\mathrm{CO}_{3}\right)_{2}\right.$

All analyses show over-saturation with dolomite. This causes precipitation with the formation of magnesium bicarbonates.

Gypsum $\left(\mathrm{Ca}^{2+} \mathrm{SO}_{4}{ }^{2-} 2 \mathrm{H}_{2} \mathrm{O}\right)$

The saturation index is negative for all the analyses, which indicates a saturation explained by a dissolution which enriches the waters in $\mathrm{Ca}^{2+}$ and $\mathrm{SO}^{2-}$.

Anhydrite $\left(\mathrm{Ca}^{2+} \mathrm{SO}_{4}{ }^{2-}\right)$

The saturation index shows negative values for all analyses, which indicates a saturation and thus increasing mineralization of the waters. The most important concentrations were observed in the eastern regions of Djebissa, where there is outcropping of evaporitic deposits. 


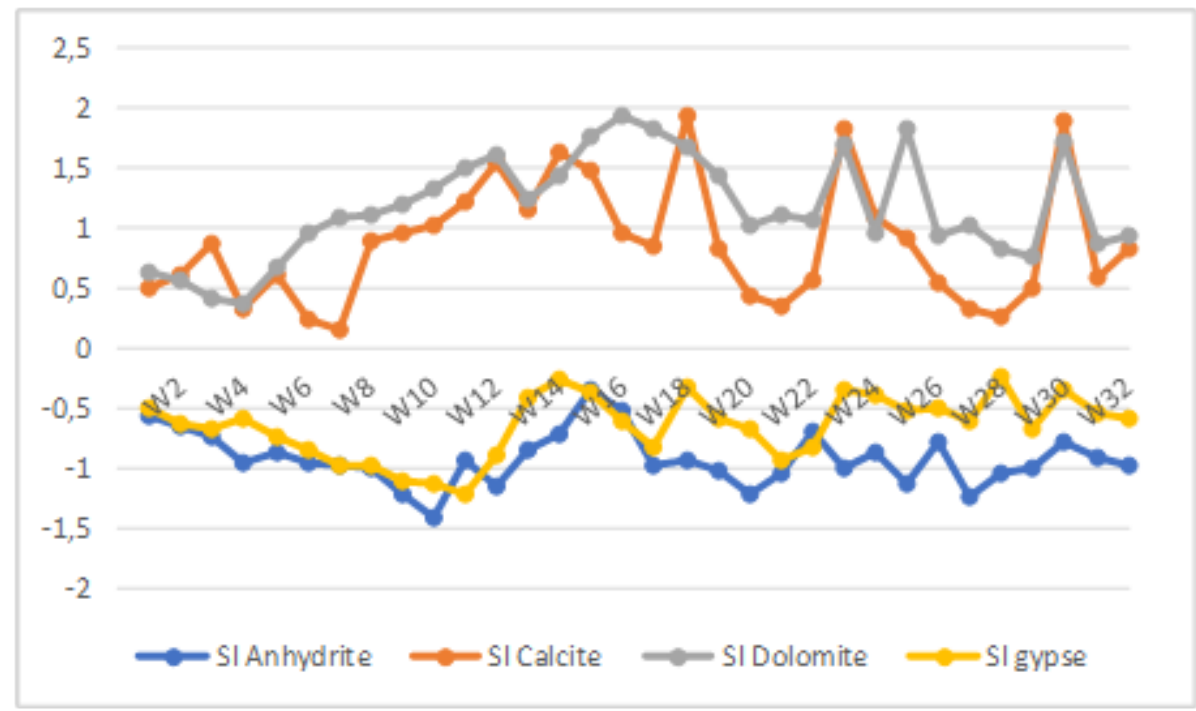

Fig.8. Evolution of water saturation indices in the area of study

\subsection{Contribution of the statistical tool}

\subsubsection{Principal component analysis (PCA)}

The PCA is a method of multidimensional statistical analysis. Each water sample from a sampling campaign constitutes a statistical unit, and the various parameters subjected to analysis constitute the variables which characterize these statistical units.

To carry out this study, we used the contents of major elements $\left(\mathrm{Ca}^{2+}, \mathrm{Mg}^{2+}\right.$, $\mathrm{Na}^{+}, \mathrm{Cl}^{-}, \mathrm{SO}_{4}{ }^{2-}, \mathrm{HCO}_{3}{ }^{-}$) as variables as well as the Electrical Conductivity (EC) and the $\mathrm{Sr}^{2+} / \mathrm{Ca}^{2+}$ ratio, using the SPAD V55 software).

This analysis was therefore carried out on a data table of eight variables with 32 individuals taken from eight sampling companions, distributed over the entire plain. Table 1 clearly shows the correlation coefficient between the initial variables. 
Table 1. Correlation coefficient between the initial variables

\begin{tabular}{|c|c|c|c|c|c|c|c|c|}
\hline & $\begin{array}{c}\mathrm{Ca}^{2+} \\
(\mathrm{mg} / \mathrm{l})\end{array}$ & $\begin{array}{c}\mathrm{Mg}^{2+} \\
(\mathrm{mg} / \mathrm{l})\end{array}$ & $\begin{array}{c}\mathrm{Na}^{+} \\
(\mathrm{mg} / \mathrm{l})\end{array}$ & $\begin{array}{c}\mathrm{Cl}^{-} \\
(\mathrm{mg} / \mathrm{l})\end{array}$ & $\begin{array}{c}\mathrm{SO}_{4}^{2-} \\
(\mathrm{mg} / \mathrm{l})\end{array}$ & $\begin{array}{c}\mathrm{HCO}^{-} \\
(\mathrm{mg} / \mathrm{l})\end{array}$ & $\begin{array}{c}\mathrm{Sr}^{2+} \mathrm{Ca}^{2+} \\
(\%)\end{array}$ & $\begin{array}{c}\mathrm{EC} \\
\mu \mathrm{S} . \mathrm{cm}^{-} \\
1\end{array}$ \\
\hline $\mathrm{Ca}^{2+} \mathrm{mg} / \mathrm{l}$ & 1 & & & & & & & \\
\hline $\mathrm{Mg}^{2+} \mathrm{mg} / \mathrm{l}$ & $\mathbf{0 , 4 3}$ & 1 & & & & & & \\
\hline $\mathrm{Na}^{+} \mathrm{mg} / \mathrm{l}$ & $\mathbf{0 , 5 6}$ & 0,06 & 1 & & & & & \\
\hline $\mathrm{Cl}^{-} \mathrm{mg} / \mathrm{l}$ & $\mathbf{0 , 4 3}$ & 0,09 & $\mathbf{0 , 9 1}$ & 1 & & & & \\
\hline $\mathrm{SO}_{4}^{2-} \mathrm{mg} / \mathrm{l}$ & $\mathbf{0 , 8 6}$ & $\mathbf{0 , 4 9}$ & $\mathbf{0 , 7 3}$ & $\mathbf{0 , 8 5}$ & 1 & & & \\
\hline $\mathrm{HCO}_{3}{ }^{-} \mathrm{mg} / 1$ & $\mathbf{0 , 7 9}$ & $\mathbf{0 , 6 9}$ & $\mathbf{0 , 3 1}$ & $-0,35$ & $-0,46$ & 1 & & \\
\hline $\mathrm{Sr}^{2+} / \mathrm{Ca}^{2+} \% \mathbf{0}$ & $\mathbf{0 , 3 7}$ & 0,18 & $\mathbf{0 , 4 7}$ & $\mathbf{0 , 7 9}$ & $\mathbf{0 , 6 4}$ & $-0,06$ & 1 & \\
\hline${\mathrm{CE} \mu \mathrm{S} . \mathrm{cm}^{-1}}^{-1}$ & 0,16 & $-0,07$ & $\mathbf{0 , 7 3}$ & $\mathbf{0 , 9 2}$ & $\mathbf{0 , 9 4}$ & $-0,19$ & $\mathbf{0 , 7 1}$ & 1 \\
\hline
\end{tabular}

\subsubsection{Analysis of the PCA circle}

The two axes F1-F2, forming the circle (Fig. 9), represent $60.97 \%$ of the variance and, therefore, express most of the information provided. Thus, in the space of variables, the main axis of inertia F1 expresses $39.81 \%$ of the information and is defined positively by the Electrical conductivity, the variables $\mathrm{Cl}^{-}, \mathrm{SO}_{4}{ }^{2-}, \mathrm{Na}^{+}, \mathrm{Ca}^{2+}, \mathrm{Mg}^{2+}$, and the $\mathrm{Sr}^{2+} / \mathrm{Ca}^{2+}$ ratio, and, therefore, represents an axis of mineralization. The axis of inertia $\mathrm{F} 2$ expresses $21.16 \%$ of the variance and is determined by bicarbonates. Note that the elements located in the positive part of the first quadrant could have the same origin; they would come from salt formations present in the region. The bicarbonates stand out from the other elements, which shows a different origin. The projection of the variables on the F1-F2 factorial plane shows that the F1 axis opposes mineralized water to weakly loaded water, this axis is slightly characterized by bicarbonates, close to neutrality. 


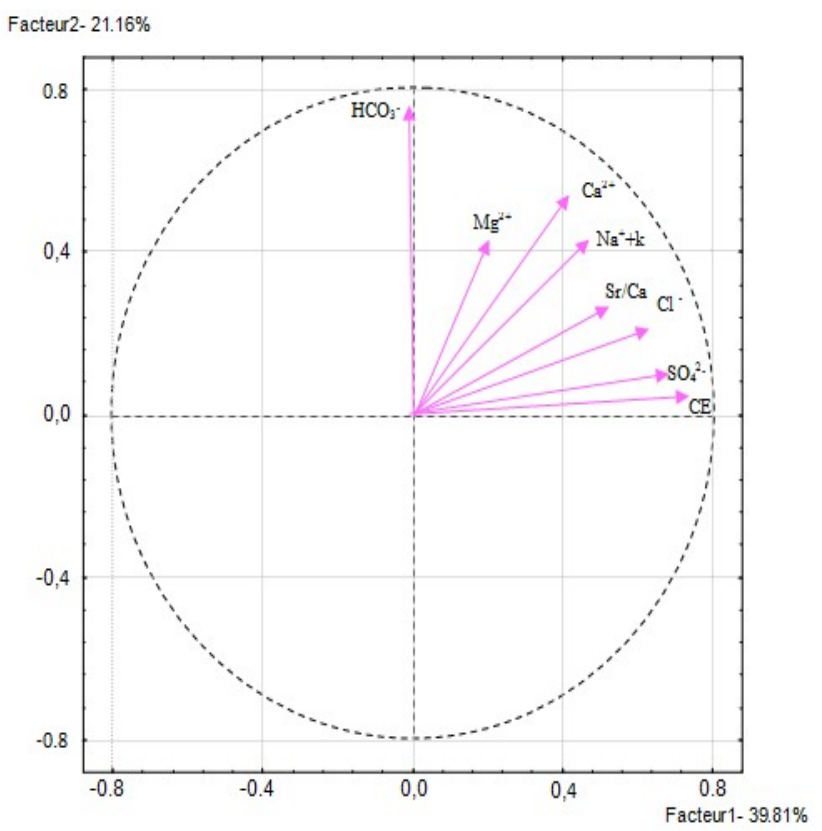

\subsubsection{Analysis of the space of individuals}

The projection of individuals on the F1-F2 plane showed the existence of three groups:

- The first group marked by a competition between cations, that is to say, an exchange between alkalis and alkaline earths;

- The second group shows the influence of chlorides and sulphates on the mineralization;

- The latter would be due to the summation of these two elements (anions). Bicarbonates alone form a third group (Fig.10). 


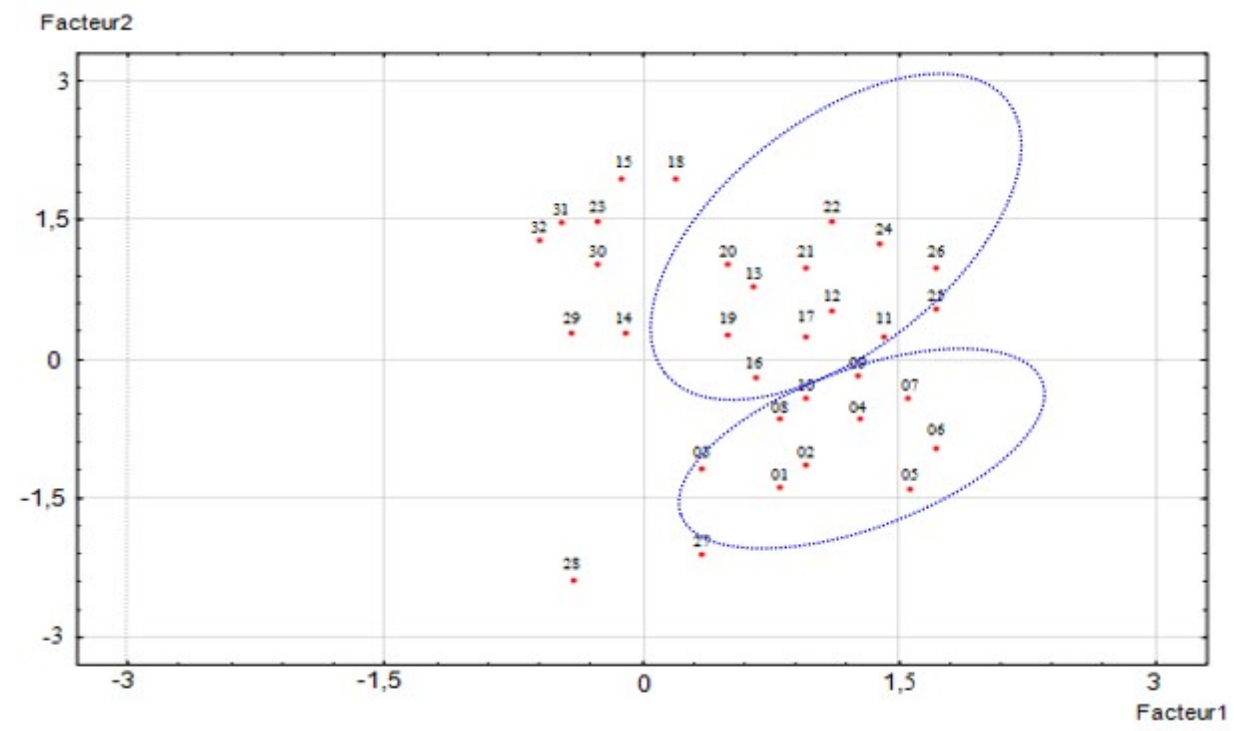

Fig.10. Projection of individuals on the plane formed by the first two axes

\section{CONCLUSION}

This study concerns the water quality of a region characterized by the heterogeneity of outcropping formations. The elements that have the most impact on the quality of the waters in the region are of geological origin. The analysis of the results obtained show that the measured Electrical conductivity values oscillate between 300 and $8000 \mu \mathrm{Scm}^{-1}$. The highest values are recorded in the east of the study area, which is due to the gypsum formations in the region.

The high concentrations of calcium ion are recorded in the wells of the three zones, around $300 \mathrm{mg} / \mathrm{l}$, coming from the dissolution of the gypsiferous formations in the east and the dissolution of the carbonate formations in the center and west of the zone of study.

Magnesium concentrations vary between $70 \mathrm{mg} / \mathrm{l}$ and $140 \mathrm{mg} / \mathrm{l}$. This last value is observed in the region of Ain Chabro due to the dilution of the dolomitic limestones of the borders.

Elevated sodium values are observed in the east of the study region, reaching $400 \mathrm{mg} / 1$. 
This concentration gradually decreases as it moves towards the center and west of the plain due to the phenomenon of base exchanges between water and clay formations.

Significant chloride values are recorded in the Djebissa area $(1200 \mathrm{mg} / 1)$. This value decreases moving towards the zone of Tebessa and Ain Chabro, to reach $100 \mathrm{mg} / \mathrm{l}$, influenced by the limestone borders. The dissolution of the evaporites in the region of Djebissa gave high values of sulphates, around $900 \mathrm{mg} / 1$. Significant concentrations of bicarbonates are observed in the Ain Chabro area $(630 \mathrm{mg} / 1)$ due to the leaching of bicarbonate formations from the borders.

The $\mathrm{Sr}^{2+} / \mathrm{Ca}^{2+}$ ratio gave significant values, confirming the impact of evaporite formations on the chemical composition of the water.

The calculation of the water saturation index indicated supersaturation favoring the precipitation of dolomite and calcite and an undersaturation allowing the dissolution of anhydrite and gypsum. These variations are an accelerator of the water salinity process. Principal component analysis yielded $60.97 \%$ of the information for both axes, thus confirming the origin of the chemical elements.

\section{ACKNOWLEDGEMENTS}

At the end, we would like to appreciate all the people and institutions who contributed to the realization of this work, in particular the Water Resource Laboratory \& Sustainable development (REDD), University of Annaba, Algeria and the Civil Engineering and Hydraulic Laboratory University of 8 May 1945 Guelma, Algeria.

\section{REFERENCES}

1. Baawain, MS and Al-Futaisi, AM 2014. Studying Groundwater Quality Affected by Barka Dumping Site: An Integrated Approach. Arabian Journal for Science and Engineering 39, 5943-5957. https://doi.org/10.1007/s13369-014-1197-1

2. Bakalowicz, M 1988. The formation of travertines: geochemical aspects. Synthesis and discussion essay $\mathrm{n}{ }^{\circ}$ XVII, U.A. 903 CNRS et ATP PIREN Aix en Provence.

3. CARRE, J 1975. Geochemistry of Strontium in groundwater and surface water in the Paris region. Thesis 3rd cycle University. Paris VI.

4. Derradji, EF et al. 2011. Evaluation of Salinity, Organic and Metal Pollution in Groundwater of the Mafragh Watershed, NE Algeria. Arabian Journal for Science and Engineering 36, 573-580.

https://doi.org/10.1007/s13369-011-0052-x 
5. Fehdi, C et al. 2009. The hydrogeochemical characterization of Morsott-El Aouinet aquifer, Northeastern Algeria. Environmental Geology 58, 16111620.

6. Fehdi, C et al. B 2015. Characterization of the main karst aquifers of the Tezbent Plateau, Tebessa Region, Northeast of Algeria, based on hydrogeochemical and isotopic data. Environmental Earth Sciences 74, 241-250.

https://doi.org/10.1007/s 12665-015-4480-x

7. Fehdi, $C$ et al. 2016. Hydrochemical and microbiological quality of groundwater in the Merdja area, Tébessa, North-East of Algeria. Applied Water Science 6, 47-55.

https://doi.org/10.1007/s13201-014-0209-3

8. Loys Naus, F et al. 2019. Influence of landscape features on the large variation of shallow groundwater salinity in southwestern Bangladesh, Journal of Hydrology X 5, 100043.

https://doi.org/10.1016/j.hydroa. 100043

9. Ghrieb, L 2011. Impact of the Triassic formations on the water and the soil of the plain in semi-arid zone: Case of the plain of Bekkaria-Tebessa (East of Algeria), $\mathrm{PhD}$ thesis. University of Annaba.

10. Grützmacher, $G$ et al. 2013. Geogenic groundwater contaminationdefinition, occurrence and relevance for drinking water production. Zentralblatt für Geologie und Paläontologie 1,69-75.

11. Haj-Amor, Z and Bouri, S 2019. Subsurface Drainage System Performance, Soil Salinization Risk, and Shallow Groundwater Dynamic Under Irrigation Practice in an Arid Land. Arabian Journal for Science and Engineering 44, 467-477. https://doi.org/10.1007/s13369-018-3606-3

12. Hsissou, $Y$ et al. 1995. Characterization of the waters of the Turonian aquifer of the Tadla basin (Morocco) by the ratio of $\mathrm{Sr}^{2+} / \mathrm{Ca}^{2+}$ molar concentrations. Journal of Hydrology 183,445-451.

13. Isher, R and Mullican, IIIW 1997. Hydrochemical Evolution of SodiumSulphate and Sodium-Chloride Groundwater Beneath the Northern Chihuahuan Desert, Trans-Pecos, Texas, USA. Hydrogeology Journal 5, 416. https://doi.org/10.1007/s100400050102

14. Banda, KE et al. 2019. Mechanism of salinity change and hydrogeochemical evolution of groundwater in the Machile-Zambezi Basin, South-western Zambia. Journal of African Earth Sciences 153, 72-82. https://doi.org/10.1016/j.jafrearsci.2019.02.022. 
15. Kumar, $P$ and Kumar, $P$ 2019. Removal of cadmium (Cd-II) from aqueous solution using gas industry-based adsorbent. SN Applied Sciences 1:365, 18. https://doi.org/10.1007/s42452-019-0377-8

16. Akbari, $M$ et al. 2020. The effects of climate change and groundwater salinity on farmers' income risk. Ecological Indicators 110, 105893. https://doi.org/10.1016/j.ecolind.2019.105893.

17. Meybeck, M 1984. Rivers and the geochemical cycle of the elements, $\mathrm{PhD}$ thesis. Paris VI: ENSup.

18. Nag, SK 2014. Evaluation of Hydrochemical Parameters and Quality Assessment of the Groundwater in Gangajalghati Block, Bankura District, West Bengal, India. Arabian Journal for Science and Engineering 39, 5715-5727. https://doi.org/10.1007/s13369-014-1141-4

19. Naik, PK et al. 2009. Hydrogeochemistry of the Koyna River basin, India. Environmental Earth Sciences 59, 613-629.

20. Parkhurst, DL and Appelo, CAJ 1999. User's guide to PHREEQC (version 2): a computer program for speciation, batch reaction, one dimensional transport, and inverse geochemical calculations. Water-Resources Investigations Report 99-4259, 1-327.

21. Rouabhia, A et al. 2008. Hydrochemical and isotopic investigation of a sandstone aquifer groundwater in a semi-arid region, El Ma El Abiod, Algeria. Environmental Geology 57:1699- 1705.

22. Rouabhia, A et al. 2009. Impact of human activities on quality and geochemistry of groundwater in the Merdja area, Tebessa, Algeria. Environmental Geology 56, 1259-1268. https://doi.org/10.1007/s00254-008-1225-0

23. Rouabhia, A et al. 2010. Impact of agricultural activity and lithology on groundwater quality in the Merdja area, Tebessa, Algeria. Arabian Journal of Geosciences 3, 307-318. https://doi.org/10.1007/s12517-009-0087-4

24. Subba Rao, N 200. Geochemistry of Groundwater in Parts of Guntur District, Andhra Pradesh, India. Environmental Geology 41, 552-562.

25. Sharaf, MAM 2013. Trace Elements Hydrochemistry and Suitability of the Groundwater in Wadi An Numan Area, Makkaah District, Western Arabian Shield, Saudi Arabia. Arabian Journal for Science and Engineering 38, 1871-1887. https://doi.org/10.1007/s13369-012-0399-7

26. Xiao, $\mathrm{J}$ et al. 2015. Hydrochemical characteristics, controlling factors and solute sources of groundwater within the Tarim River Basin in the extreme arid region, NW Tibetan Plateau. Quaternary International 380, 237-246. 
PHYSICOCHEMICAL CHARACTERIZATION OF THE QUALITY

https://doi.org/10.1016/j.quaint.2015.01.021

27. Yao, $\mathrm{Z}$ et al. 2015. Spatial-temporal patterns of major ion chemistry and its controlling factors in the Manasarovar Basin, Tibet. Journal of Geographical Sciences 25, 687-700.

https://doi.org/10.1007/s11442-015-1196-5

Editor received the manuscript: 26.03.2021 